\title{
Implementation of Anaerobic Soil Disinfestation in Florida Tomato Production'
}

\author{
Bodh R. Paudel, Francesco Di Gioia, Qiang Zhu, Xin Zhao, Monica Ozores-Hampton, Marilyn E. \\ Swisher, Kaylene Sattanno, Jason C. Hong, and Erin N. Rosskopf ${ }^{2}$
}

\section{What is anaerobic soil disinfestation?}

Anaerobic soil disinfestation (ASD), also known as biological or reductive soil disinfestation or soil reductive sterilization, is a nonchemical soil treatment alternative to chemical fumigation for the management of soilborne diseases, nematodes, and weeds (Blok et al. 2000; Katase et al. 2009; Momma et al. 2013; Rosskopf et al. 2015; Shinmura et al. 1999). This concept was developed in Japan (Shinmura et al. 1999) and the Netherlands (Blok et al. 2000) for smallscale farming and protected culture. Large-scale open-field research is currently underway in Florida and California to determine the effectiveness of ASD in conventional and organic crop production systems. This preplant method consists of creating anaerobic soil conditions by incorporating readily decomposable carbon $(\mathrm{C})$ sources and soil amendments, irrigating the soil to field capacity, and covering the soil with gas-impermeable mulch for a period of approximately three weeks (Butler et al. 2012; Di Gioia et al. 2016; Guo et al. 2017). ASD is effective against numerous soilborne plant pathogens, plant-parasitic nematodes, and weeds because the process depletes available soil oxygen, shifts soil microbial composition to facultative anaerobes, lowers soil $\mathrm{pH}$, and releases short-chain fatty acids (e.g., acetic, butyric, lactic, citric, isovaleric, and propionic acids), aldehydes, alcohols, ammonia, metal ions $\left(\mathrm{Mn}^{2+}\right.$ and $\left.\mathrm{Fe}^{2+}\right)$, and other volatile organic compounds (Guo et al. 2018; Johns et al. 2017; Momma 2008; Momma et al. 2006; Oka 2010; van Agtmaal et al. 2015).

Different C sources, additional soil amendments, temperature, and application methods (Paudel et al. 2018) have high impacts on the success of ASD. Commonly used C sources include rice or wheat bran, green manure, molasses, and ethanol (Strauss and Kluepfel 2015). Locally available and affordable $\mathrm{C}$ sources are important to reduce the cost of ASD. Preplant fertilizers may be needed to stimulate microbial activity, depending on the amount of available nutrients from the $\mathrm{C}$ source and soil amendment (Di Gioia et al. 2017). The following ASD implementation procedure, which combines the application of composted poultry litter (CPL, soil amendment) with molasses (C source), is currently used in Florida. Yields in field trials of this method have demonstrated comparable or higher tomato marketable yield compared to standard chemical soil fumigation practices (Table 1).

1. This document is HS1345, one of a series of the Horticultural Sciences Department, UF/IFAS Extension. Original publication date November 2019. Visit the EDIS website at https://edis.ifas.ufl.edu for the currently supported version of this publication.

2. Bodh R. Paudel, postdoctoral associate, Horticultural Sciences Department; Francesco Di Gioia, assistant professor, Plant Science Department, Pennsylvania State University; Qiang Zhu, postdoctoral associate; Xin Zhao, associate professor, Horticultural Sciences Department; Monica OzoresHampton, former associate professor, Horticultural Sciences Department, UF/IFAS Southwest Florida Research and Education Center; Marilyn E. Swisher, professor; Kaylene Sattanno, research coordinator, Department of Family, Youth and Community Sciences; Jason C. Hong, research plant pathologist; and Erin N. Rosskopf, research microbiologist, USDA, ARS, United States Horticultural Research Laboratory; UF/IFAS Extension, Gainesville, FL 32611.

The Institute of Food and Agricultural Sciences (IFAS) is an Equal Opportunity Institution authorized to provide research, educational information and other services

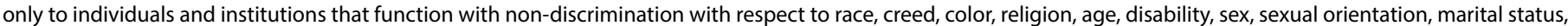

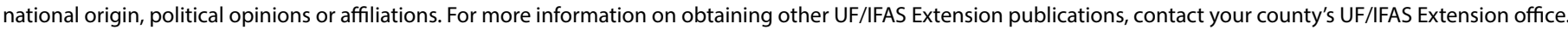
U.S. Department of Agriculture, UF/IFAS Extension Service, University of Florida, IFAS, Florida A \& M University Cooperative Extension Program, and Boards of County Commissioners Cooperating. Nick T. Place, dean for UF/IFAS Extension. 


\section{How does one implement anaerobic soil disinfestation in field tomato production?}

The implementation of ASD involves a series of steps starting with applying the treatment, then covering raised beds with totally impermeable film (TIF) and applying drip irrigation, all of which have to occur on the same day. The most common waiting period between ASD application and transplanting tomato is three weeks. After three weeks, growers can punch planting holes in the TIF and follow other normal field planting procedures.

\section{First Step:}

Three weeks prior to transplanting, broadcast the bottom mix fertilizers (containing 10\%-20\%, 100\%, and 10\%-20\% of the total season nitrogen, phosphorus, and potassium fertilizers, respectively) on the surface of the soil where beds will be located (Figure 1).

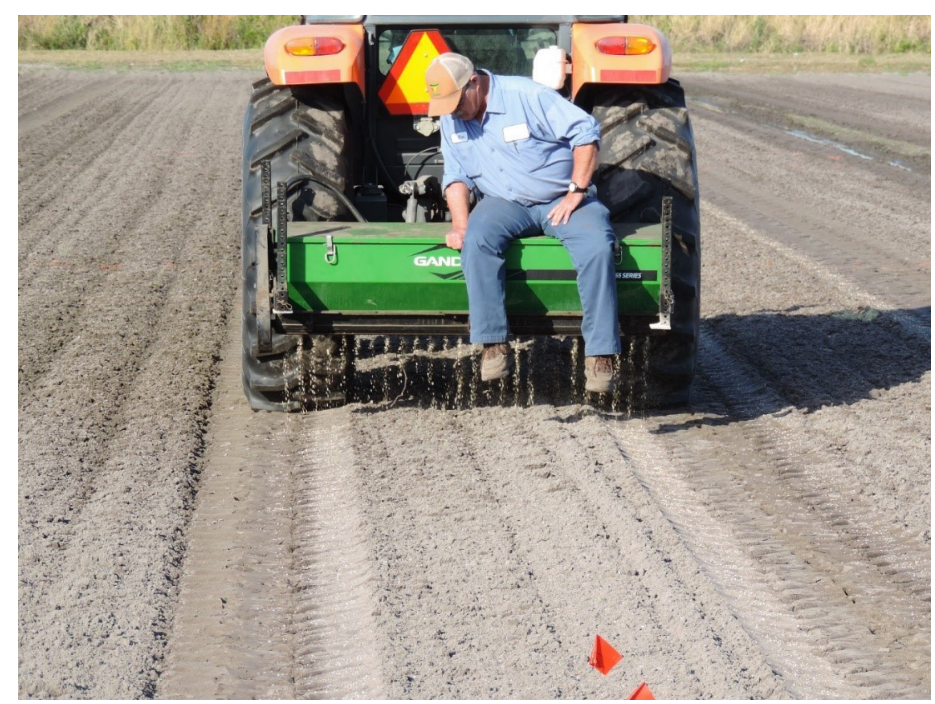

Figure 1. Bottom mix fertilizer application.

Credits: F. Di Gioia

\section{Second Step:}

Form the false beds approximately 4 inches high (Figure 2) and apply CPL and molasses (Table 2; Figures 3 and 4).

The soil amendments and C sources may be broadcast applied to the entire soil surface or banded. Soil amendments and $\mathrm{C}$ sources are applied only to the bed area in Florida and most locations where raised-bed systems are used. Two different methods for calculating the amount of CPL needed for ASD on a 600-foot-long and 3-foot-wide bed are given below.

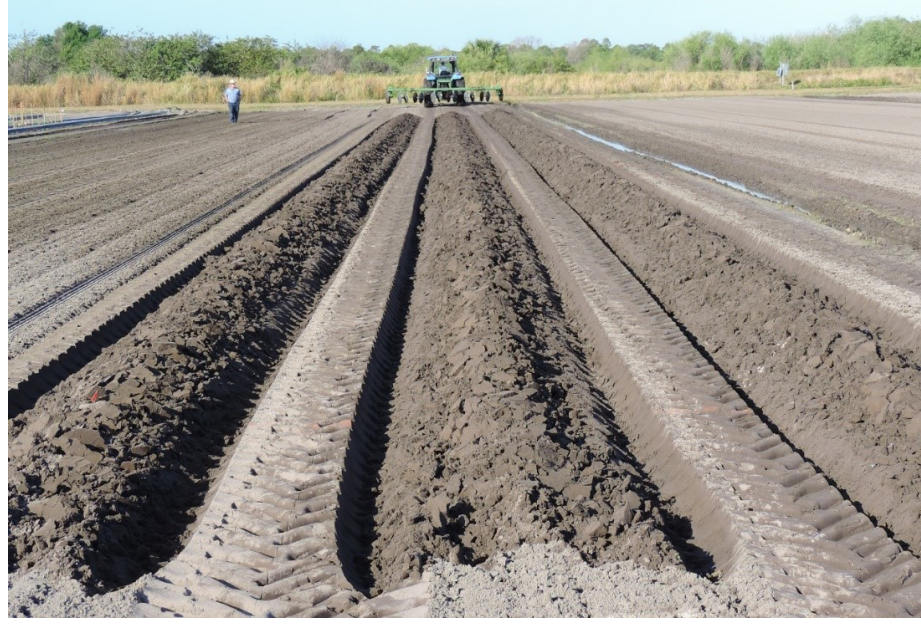

Figure 2. False bed formation.

Credits: F. Di Gioia

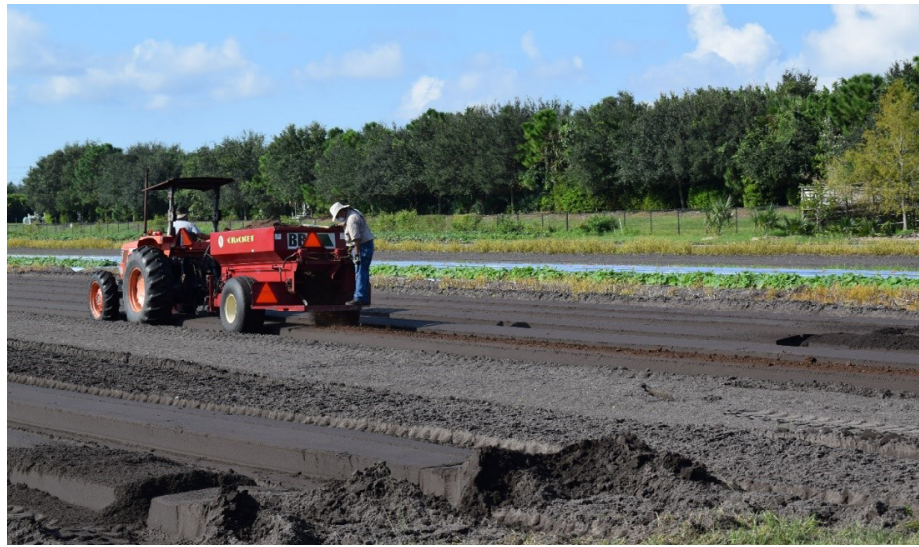

Figure 3. Composted poultry litter application.

Credits: K. Sattanno, UF/IFAS

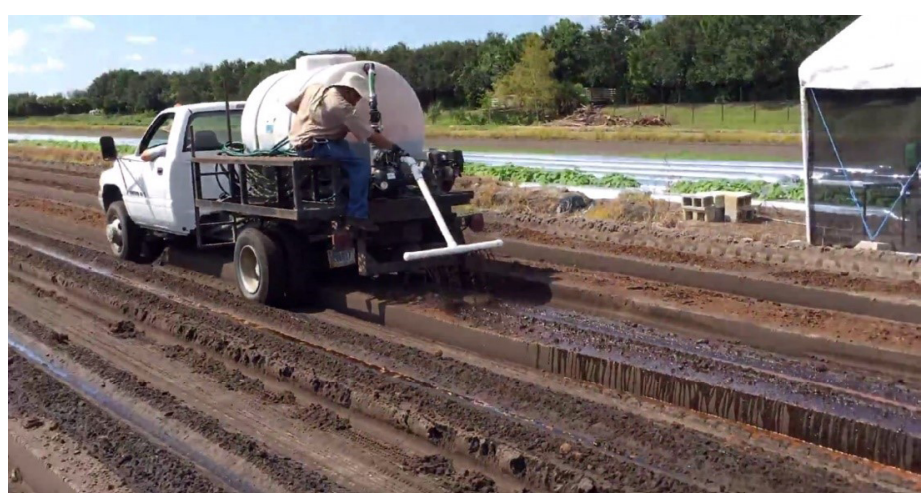

Figure 4. Molasses application.

Credits: E. N. Rosskopf

\section{Using the broadcast application rate of composted poultry litter (4.5 tons/acre) and bed width to calculate the actual bed surface:}

a. A short ton is equivalent to $2,000 \mathrm{lb}$; therefore, 4.5 tons/acre $\times 2,000 \mathrm{lb} /$ ton $=9,000 \mathrm{lb} /$ acre 
b. There are $43,560 \mathrm{sq} f \mathrm{ft}$ in one acre, resulting in an application rate per sq ft calculated as: 9,000 lb/acre / $43,560 \mathrm{sq} \mathrm{ft} / \mathrm{acre}=0.207 \mathrm{lb} / \mathrm{sq} \mathrm{ft}$

c. For a $600 \mathrm{ft}$ by $3 \mathrm{ft}$ bed, the actual area of the bed is $600 \mathrm{ft} \times 3 \mathrm{ft}=1,800 \mathrm{sq} \mathrm{ft}$

d. This results in a total amount of material calculated as $0.207 \mathrm{lb} / \mathrm{sq} \mathrm{ft} \times 1,800 \mathrm{sq} \mathrm{ft}=372 \mathrm{lb}$

2. Using the linear bed feet (LBF) system, consider the bed spacing is $6 \mathrm{ft}$ and the bed width is $3 \mathrm{ft}$, only half of the soil surface is treated, therefore the actual application rate of composted poultry litter to the raised beds is 2.25 tons/acre:

a. A short ton is equivalent to $2,000 \mathrm{lb}$; therefore, 2.25 tons/acre $\times 2,000 \mathrm{lb} /$ ton $=4,500 \mathrm{lb} /$ acre

b. Given that there are $43,560 \mathrm{sq} f \mathrm{ft}$ one acre and that the beds are $6 \mathrm{ft}$ apart (from center to center), the $\mathrm{LBF} / \mathrm{acre}$ is calculated as $43,560 \mathrm{sq} \mathrm{ft} / \mathrm{acre} / 6 \mathrm{ft}=$ $7,260 \mathrm{ft} /$ acre

c. There are $7,260 \mathrm{ft} / \mathrm{acre}$, the application rate per $\mathrm{LBF}$ is calculated as: $4,500 \mathrm{lb} / \mathrm{acre} / 7,260 \mathrm{ft} / \mathrm{acre}=0.62 \mathrm{lb} / \mathrm{ft}$

d. The total amount of organic material required is calculated as $0.62 \mathrm{lb} / \mathrm{ft} \times 600 \mathrm{ft}=372 \mathrm{lb}$

\section{Third Step:}

Till the amended soil to a depth of 8 inches with a rotary cultivator (Figure 5), reform the beds, and cover with TIF while simultaneously placing two drip tapes under the plastic mulch 8 inches from the bed center and 1 inch below the soil surface (Figure 6).

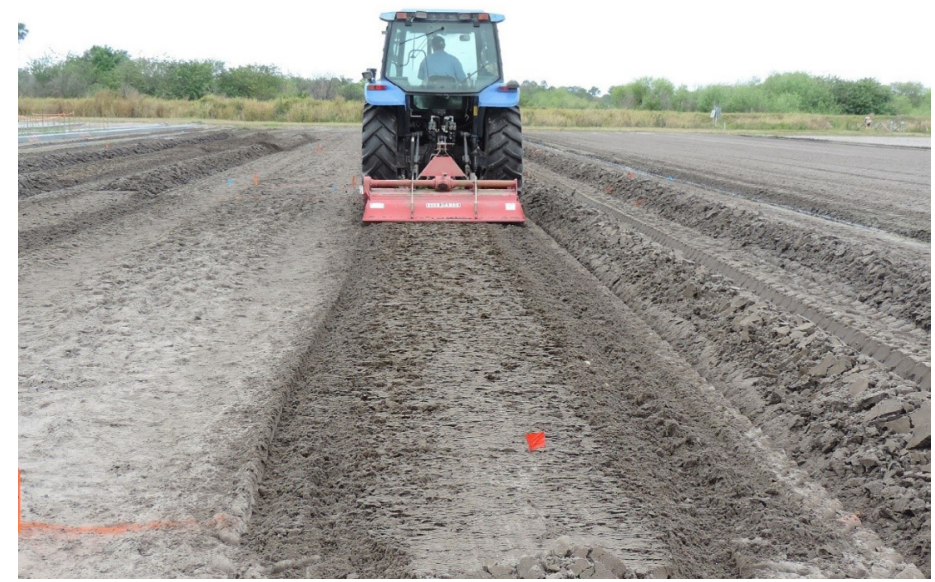

Figure 5. Rotary cultivation of the amended bed.

Credits: F. Di Gioia

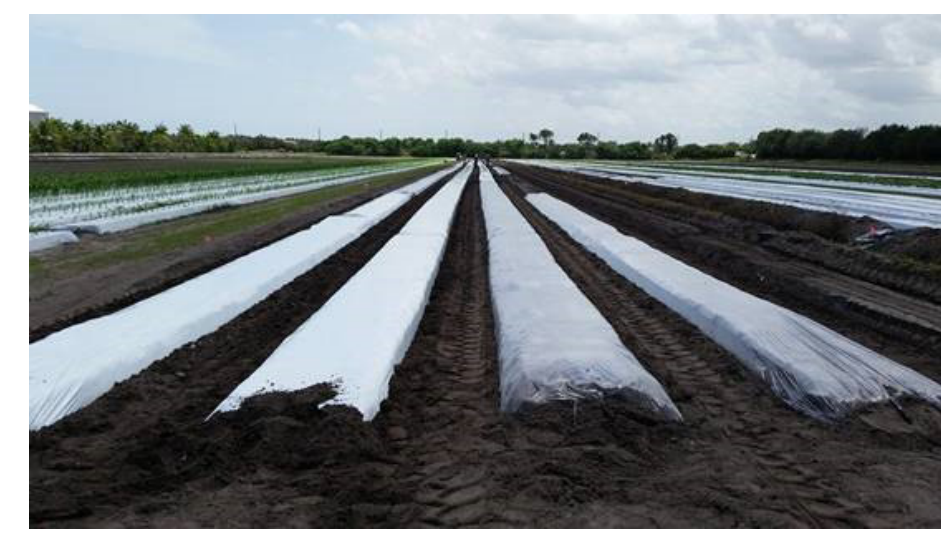

Figure 6. Beds covered with TIF plastic mulch. Credits: J. C. Hong

\section{Fourth Step:}

Irrigate the soil with 2 acre-inches of water (approximately 4-5 hours using two drip lines with $0.65 \mathrm{gpm} / 100 \mathrm{ft}$ at 10 psi) to fill the pore space. The irrigation amount can be calculated as follows:

a. Water requirement for a 600 -foot-long and 3-footwide bed $(600 \mathrm{ft} \times 3 \mathrm{ft}=1,800 \mathrm{sq} f \mathrm{ft}): 1,800 \mathrm{sq} \mathrm{ft} \times 2$ inches $\times 0.0833 \mathrm{ft} / \mathrm{inch})=299.88$ cubic $\mathrm{ft}=2,243.1$ gals

b. The flow rate of the drip tape at 10 psi is 0.65 $\mathrm{gpm} / 100 \mathrm{ft}(0.0065 \mathrm{gpm} / \mathrm{ft})$; therefore, to irrigate a 600-foot-long bed the flow requirement is: 0.0065 $\mathrm{gpm} / \mathrm{ft} \times 600 \mathrm{ft} \times 2$ drip lines $=7.8 \mathrm{gpm}$

c. Thus, the time needed to run the irrigation will be: $2,243.1$ gals $/ 7.8 \mathrm{gpm}=288$ minutes $=4.8$ hours

\section{Acknowledgements}

The authors acknowledge the Areawide Project on ASD funded by USDA, Agricultural Research Service. For updated information about ASD in Florida, including publications, presentations, and reports, visit https://floridafoodandag.com/new-home/anaerobic-soil-disinfestation-asd

\section{References}

Blok, W. J., J. G. Lamers, A. J. Termorshuizen, and G. J. Bollen. 2000. "Control of Soilborne Plant Pathogens by Incorporating Fresh Organic Amendments Followed by Tarping." Phytopath. 90: 253-259. https://apsjournals. apsnet.org/doi/10.1094/PHYTO.2000.90.3.253

Butler, D. M., N. Kokalis-Burelle, J. Muramoto, C. Shennan, T. G. McCollum, and E. N. Rosskopf. 2012. "Impact of Anaerobic Soil Disinfestations Combined with Soil 
Solarization on Plant-Parasitic Nematodes and Introduced Inoculum of Soilborne Plant Pathogens in Raised-Bed Vegetable Production." Crop Prot. 39: 33-40. https://www. sciencedirect.com/science/article/pii/S0261219412000804

Di Gioia, F., M. Ozores-Hampton, J. Hong, N. KokalisBurelle, J. Albano, X. Zhao, Z. Black, Z. Gao, C. Wilson, J. Thomas, K. Moore, M. Swisher, H. Guo, and E. N. Rosskopf. 2016. "The Effects of Anaerobic Soil Disinfestation on Weed and Nematode Control, Fruit Yield, and Quality of Florida Fresh-Market Tomato." Hortscience 51: 703-711. https:// journals.ashs.org/hortsci/view/journals/hortsci/51/6/ article-p703.xml

Di Gioia, F., M. Ozores-Hampton, X. Zhao, J. Thomas, P. Wilson, Z. Li, J. Hong, J. Albano, M. Swisher, and E. N. Rosskopf. 2017. "Anaerobic Soil Disinfestation Impact on Soil Nutrients Dynamics and Nitrous Oxide Emissions in Fresh-Market Tomato." Agr. Ecosyst. Environ. 240: 194-205. https://www.sciencedirect.com/science/article/pii/ S0167880917300889

Guo, H., F. Di Gioia, X. Zhao, M. Ozores-Hampton, M. E. Swisher, J. Hong, N. Kokalis-Burelle, A. N. DeLong, and E. N. Rosskopf. 2017. "Optimizing Anaerobic Soil Disinfestation for Fresh Market Tomato Production: Nematode and Weed Control, Yield, and Fruit Quality." Scientia Hort. 218: 105-116. https://www.sciencedirect.com/science/article/pii/ S0304423817300857

Guo, H., X. Zhao, E. N. Rosskopf, F. Di Gioia, J. Hong, and D. H. McNear Jr. 2018. "Impacts of Anaerobic Soil Disinfestation and Chemical Fumigation on Soil Microbial Communities in Field Tomato Production System." Appl. Soil Ecol. 126: 165-173. https://www.sciencedirect.com/ science/article/pii/S092913931730481X

Johns, C., A. Lee, T. Springer, E. N. Rosskopf, J. C. Hong, W. Turechek, N. Kokalis-Burelle, and N. Finley. 2017. "Using NMR-based Metabolomics to Monitor the Biochemical Composition of Agricultural Soils: A Pilot Study." Eur. J. Soil Biol. 83: 98-105. https://www.sciencedirect.com/ science/article/pii/S1164556317302650

Katase, M, C. Kubo, S. Ushio, E. Ootsuka, T. Takeuchi, and T. Mizukubo. 2009. "Nematicidal Activity of Volatile Fatty Acids Generated from Wheat Bran in Reductive Soil Disinfestation." Nematol. Res. 39: 53-62. https://www.jstage. jst.go.jp/article/jjn/39/2/39_2_53/_article
Momma, N. 2008. "Biological Soil Disinfestation (BSD) of Soilborne Pathogens and Its Possible Mechanisms." Jpn. Agr. Res. Q. 42: 7-12. https://www.jstage.jst.go.jp/article/ jarq/42/1/42_7/_article

Momma, N., K. Yamamoto, P. Simandi, and M. Shishido. 2006. "Role of Organic Acids in the Mechanisms of Biological Soil Disinfestation (BSD)." J. Gen. Plant Pathol. 72: 247-252. https://link.springer.com/article/10.1007/ s10327-006-0274-Z

Momma, N., Y. Kobara, S. Uematsu, N. Kita, and A. Shinmura. 2013. "Development of Biological Soil Disinfestations in Japan.” Appl. Microbiol. Biot. 97: 3801-3809. https://link. springer.com/article/10.1007\%2Fs00253-013-4826-9

Oka, Y. 2010. "Mechanisms of Nematode Suppression by Organic Soil Amendments-A Review." Appl. Soil Ecol. 44: 101-115. https://www.sciencedirect.com/science/article/pii/ S0929139309001942

Paudel, B. R., F. Di Gioia, X. Zhao, M. Ozores-Hampton, J. C. Hong, N. Kokalis-Burelle, C. Pisani, and E. N. Rosskopf. 2018. "Evaluating Anaerobic Soil Disinfestation and Other Biological Soil Management Strategies for Open-Field Tomato Production in Florida." Renew. Agr. Food Syst. 1-12. https://doi.org/10.1017/S1742170518000571

Rosskopf, E., P. Serrano-Pérez, J. Hong, U. Shrestha, M. C. Rodríguez-Molina, K. Martin, N. Kokalis-Burelle, C. Shennan, J. Muramoto, and D. Butler. 2015. "Anaerobic Soil Disinfestation and Soil Borne Pest Management.” In Organic Amendments and Soil Suppressiveness in Plant Disease Management; Soil Biology Vol 46, edited by Meghvansi and Varma. 277-305. Springer. https://link.springer. com/chapter/10.1007/978-3-319-23075-7_13

Shinmura, A., N. Sakamoto, and H. Abe. 1999. "Control of Fusarium Root Rot of Welsh Onion by Soil Reduction." (Abstract in Japanese). Jpn. J. Phytopathol. 65: 352-353.

Strauss, S. L., and D. A. Kluepfel. 2015. "Anaerobic Soil Disinfestation: A Chemical-Independent Approach to Pre-plant Control of Plant Pathogens." J. Integr. Agr. 14: 2309-2318. https://www.sciencedirect.com/science/article/ pii/S2095311915611182 
van Agtmaal, M., G. J. van Os, W. G. Hol, M. P. J.

Hundscheid, W. T. Runia, C. A. Hordijk, and W. de Boer.

2015. "Legacy Effects of Anaerobic Soil Disinfestation on

Soil Bacterial Community Composition and Production

of Pathogen-Suppressing Volatiles." Front. Microbiol.

6: 1-12. https://www.frontiersin.org/articles/10.3389/

fmicb.2015.00701/full

Table 1. Effects of soil treatments on total season marketable tomato yield (three harvests combined) in Immokalee, Florida (adapted from Guo et al. 2017).

\begin{tabular}{|c|c|c|c|c|}
\hline \multirow[t]{2}{*}{ Treatment } & \multicolumn{4}{|c|}{$\begin{array}{c}\text { Total Season Harvest } \\
\text { (25 lb boxes/acre) }\end{array}$} \\
\hline & $\mathbf{X} \mathbf{L}^{\mathbf{z}}$ & $\mathbf{L}$ & M & TMY \\
\hline $\mathrm{CSF}^{y}$ & $1021 \mathrm{c}$ & $382 \mathrm{a}$ & $161 \mathrm{a}$ & $1564 \mathrm{~b}$ \\
\hline ASD 0.5 & $1325 b$ & $243 b$ & $75 \mathrm{~b}$ & $1643 b$ \\
\hline ASD 1.0 & $1582 \mathrm{a}$ & $286 \mathrm{~b}$ & $107 \mathrm{~b}$ & 1975 a \\
\hline \multicolumn{5}{|c|}{$\begin{array}{l}{ }^{z} \mathrm{XL}=\text { extra-large }(>2.75 \mathrm{in}), \mathrm{L}=\text { large }(2.50 \text { to } 2.78 \mathrm{in}), \mathrm{M}=\text { medium }(2.25 \text { to } 2.53 \mathrm{in}), \mathrm{TMY}=\text { total marketable yield. } \\
\text { y } \mathrm{CSF}=\text { Chemical soil fumigation with Pic-Clor } 60 ; \mathrm{ASD} 0.5=\text { Anaerobic soil disinfestation with } 741 \mathrm{gal} / \mathrm{acre} \text { of molasses and } 4.5 \mathrm{t} / \mathrm{acre} \text { of } \\
\text { composted poultry litter; ASD } 1.0=\text { Anaerobic soil disinfestation with } 1482 \mathrm{gal} / \text { acre of molasses and } 9 \mathrm{t} / \mathrm{acre} \text { of composted poultry litter. } \\
\text { Means within each column followed by the same letter were not significantly different by Fisher's Least Significant Difference test at } p \leq 0.05 \text {. }\end{array}$} \\
\hline
\end{tabular}

Table 2. Materials that can be used for a feasible field-scale application of anaerobic soil disinfestation in Florida.

\begin{tabular}{|c|c|c|c|}
\hline \multicolumn{2}{|c|}{ Material } & \multirow{2}{*}{$\begin{array}{c}\begin{array}{c}\text { Application } \\
\text { Rate (Based } \\
\text { on Raised-Bed } \\
\text { Area) }\end{array} \\
4.5 \text { tons/acre }\end{array}$} & \multirow{3}{*}{$\begin{array}{l}\qquad \text { Purpose } \\
\qquad \begin{array}{l}\text { Increases water retention and initiates rapid growth } \\
\text { and increased respiration of soil microbes, which } \\
\text { further deplete soil oxygen }\end{array}\end{array}$} \\
\hline \multirow{2}{*}{$\begin{array}{l}\text { Labile carbon sources and soil } \\
\text { amendments }\end{array}$} & Composted poultry litter (CPL) & & \\
\hline & $\begin{array}{l}\text { Sugarcane molasses (C source, } \\
\text { water diluted at a ratio of } 1: 1, \mathrm{v}: \mathrm{v} \text { ) }\end{array}$ & $\begin{array}{l}741 \mathrm{gal} / \mathrm{acre} \\
\text { (before dilution) }\end{array}$ & \\
\hline Plastic mulch & TIF & - & $\begin{array}{l}\text { Minimizes gas exchange between the soil and the } \\
\text { ambient atmosphere above the polyethylene mulch, } \\
\text { and increases soil temperature, which stimulates } \\
\text { microbial activity }\end{array}$ \\
\hline Irrigation & Two drip tapes per bed & 2 acre-inches & $\begin{array}{l}\text { Saturates air-filled pore space in the beds, enhances } \\
\text { the diffusion of by-products in the soil, and depletes } \\
\text { oxygen in the area under plastic mulch }\end{array}$ \\
\hline
\end{tabular}

